\title{
Modern Advertising Practice: Gender Images and Stereotypes Generation
}

\author{
Anel Kanatovna Naisbayeva ${ }^{1}$ Aliya Rmgazinovna Massalimova² Azhar \\ Kuanyshbekovna Zholdubayeva ${ }^{3}$ \\ ${ }^{1}$ PhD student, Cultural Studies, Al-Farabi Kazakh National University, Republic of \\ Kazakhstan. Email: anelechkago@mail.ru \\ ${ }^{2}$ Doctor of Philosophy, Professor, Al-Farabi Kazakh National Universit, \\ ${ }^{3}$ Doctor of Philosophy, Professor, Al-Farabi Kazakh National University
}

Received December 23, 2017; Revised March 10, 2018; Accepted March 20, 2018; Published May o7, 2018.

\begin{abstract}
Since nowadays mass media are not only an important institutional setting, but also an information transfer and gaining channel, they have a substantial effect on generation and fixation of gender stereotypes in public consciousness. It is for this reason that mass media are considered as one of the leverages effecting broad public consciousness. Therefore, gender images and stereotypes, which prevail in advertising texts and subjects, become permanent in consciousness of common persons. The relevance of this article is stipulated by the fact that the results of the studies extend scientific perceptions of gender stereotype phenomena, which may promote enhanced study of positive and negative gender stereotypes existing in national advertising. In this article, the main trends in the development of gender stereotypes in modern advertising practice, as well as public stereotype mentality, widespread public stereotypes along with male and female images fixed in public consciousness of people in the former Soviet republics (evidenced from Kazakhstan, Russia and Ukraine), are discussed. With a view to studying gender images and stereotypes' generation in modern advertising practice, we have carried out a sampling analysis of print (magazine) advertising published in magazines of different countries in the Russian language.
\end{abstract}

Keywords: advertising, advertising area, gender stereotypes, gender images, gender roles, gender markedness.

\section{Introduction}

The modern advertising area is distinctly characterized by emphasizing the gender characteristics, which genetically and in substance trace back to one of the most significant binary oppositions, which is "male-female" ("he-she") [1]. This supposes the necessity of comprehensive consideration of the gender aspect of advertising, which is realized in multiple projections, but is based on the interminable conflict of the male and female principles as primary archetypes.

The overwhelming majority of different advertisement messages some way or other, indirectly or directly appeal to the binary opposition of the male and female principles and to respective archetypes, which, in turn, are expressed in stereotype personages and situations reflecting gender identities and social roles. Due to translation or destruction of gender stereotypes, advertising actively influences public conscience and subconscious, thus providing

(c) AesthetixMS 2018. This Open Access article is published under a Creative Commons Attribution Non-Commercial 4.0 International License (http://creativecommons.org/licenses/by-nc/4.o/), which permits non-commercial re-use, distribution, and reproduction in any medium, provided the original work is properly cited. For citation use the DOI. For commercial re-use, please contact editor@rupkatha.com. 
the performing of the advertising function connected with creation or support of society characterized by certain features [2].

In the current context of advertising use, which reflects and simultaneously creates and imposes upon the society certain perceptions, valuables and visions, the system of gender stereotypes realized via advertising may exert both positive and negative effect on the gender psychology of the society. However, advertising gender stereotypes generally reflect the common situation existing in the media scene, not being in substantial discord with those stereotypes, which are everywhere broadcasted by mass media.

\section{Gender aspects of modern advertising practice}

The pragmatic significance of advertising discourse studies with a focus on the gender aspect is stipulated by the fact that advertising effectiveness is largely determined by the right segmentation of society (in particular, by gender concept), use of proper leverages effecting the selected segment (particularly, taking into account gender psychology), as well as by relevant presentation of different gender stereotypes existing in the society, via which the advertising concept may be encoded [3, p. 421].

Gender stereotypes should be read as stable concepts pertinent to features, merits, potentialities and behavior of genders. Stereotypes are closely connected with gender roles, which are determined by male and female social role specialization realized via the cultural practice system [4]. While discussing the issues of generation and functioning of gender stereotypes, it is necessary to keep in mind, firstly, historical, social, cultural, religious, political, age-related and other factors, as well as the gender ideology of the society (for instance, socially and economically highly-developed countries are oriented towards gender equality, while countries with low living standards and traditional cultures follow gender asymmetry). Secondly, the possibilities of stereotypes' perturbations (feminization of males and masculinization of females) should not be ignored. It is necessary to attract attention to gender autostereotypes, which means, in other words, perception of gender roles by representatives of the same culture (about themselves). It is impossible to underrate or disregard gender stereotypes, roles or autostereotypes because of their close connection with social attitudes, which are regulated at underlying and mental levels of public conscience and exert an effect on this public conscience (they are stable and go back generations, transferred from one generation to another and are changed in the course of the social evolution) [5, p. 995].

Accordingly, the correlation of the stereotype system with the historically formed (traditional) features of a certain society and a set of mental characteristics predetermines multiple cases, well-known in world advertising practice, of noncompliance of stereotypes reproduced within the international advertising campaigns with the expectations and visions of definite social environments, in media spaces of which this advertising is broadcasted, which results in reducing or even lack of its effectiveness [6].

On the one hand, in advertising field, the general specific character of the functioning of stereotypes in the media environment appears rather distinctly, while, on the other hand, particular issues associated with representativeness emerge, especially those, which have been noted by M.S. Petrov as follows: "...for advertising technologies, the breach of the causal chain of events (chronology) is quite natural", the following "sequence of actions" is possible - "...at first, the stereotype actualizes an attitude in respect to the goods, then promotes respective action and the final stage involves the sound estimation of the act of purchase" [7, p. 42]. As was noted by the 
aforementioned investigator, "...by morphology, one can distinguish stereotype images, stereotype estimates, prohibitions, prescriptions, stereotype actions and practices, stable emotional responses, which gives an indication of stereotypes' explication in different semiotic systems" [7, p. 43].

Nowadays, the gender aspect of mass communications is one of advanced lines of research in this field, though it is not frequently applied to the advertising area, especially evidenced from Kazakhstan. In a number of articles [8-9], I. Groshev has outlined that the success in the generation of advertising products directly depends on addressing permanent gender stereotypes, cogitative and behavioral formulas of males and females, rather than those reasonably recognized by them. I. Groshev has noted that gender is an extralinguistic, cognitive phenomenon, but there exist lingual modes of its designing, as well as non-lingual factors affecting this process and used in advertising generation. M. Tomskaya, while studying the gender advertising dimension based on social advertising texts, has demonstrated the prospects of its designing using lingual aids [10]. While studying such component of the gender aspect in advertising as the existence of respective stereotypes, M. Tomskaya has drawn attention to the role of mass media in the generation of gender perceptions of the society [11]. Some investigators limit themselves by studying female images in advertising from the psychological perspective [12-13]. In many cases, studies contain information on psychological and statistical investigations performed both in Western countries and in former Soviet republics. Thus, psychologists consider, that TV advertising is generated in such a manner as to strengthen the image of that particular gender (male or female), which is the most efficient for the sale of certain goods, intended for the selected targeted public [14].

However, studies aimed at a holistic view of this problem were rarely applied to the modern advertising area. Therefore, we will try to describe the basic parameters of the gender aspect realization in modern advertising practice (first of all, at the level of audience segmentation, keeping in mind gender groups and stereotype translation) in order to determine their role in the advertising area.

Concerning the gender aspect of advertising, we believe that two principle projections should be outlined. Firstly, it is pertinent to the generation of the so-called "male" and "female" advertising, in other words, the segmentation of potential audience based on the gender principle and creation of respective advertising texts taking into account gender psychology to the fullest extent. Secondly, the translation (less frequently - fixation, or alternatively - apparent destruction) of gender stereotypes existing in the society, their use as the basis for the advertising concept, generation of respective reasons and images, etc.

In the first case, we have to do with gender-oriented advertising products, where audience segmentation is realized with the purpose of the concentrated influence on the selected (targeted) group. Such advertising practice may be realized at different levels, with an emphasis on conscious or subconscious effect (via use of coloristics, images, artistic details, gender-marked language, accentuation of certain lifestyles and perceptions, via direct or indirect outlining of the "dominance" of definite gender and, respectively, positive presentation of a certain part of the respective binary opposition, etc.).

In this connection, we may find in the media scene (especially on the TV screen) many distinctly inappropriate (from the gender point of view) advertising messages, in which the authors of these messages try to obtain benevolence of representatives of one gender through the abjection of the other gender. For instance, among all gender-neutral advertisings of household appliances in the former Soviet republics, the one is as follows: "The decision on the purchase of household appliances is taken by men. This advertising is for them. And SHE takes her place"; this 
statement, presented as an axiom in the first sentence, is strengthened in the second sentence by its ambiguity, based on lexical unit "she". A similar situation may be found in the international advertising campaign of the Israeli beer "Goldstar", however presented even in a more emotional and inappropriate version. The verbal component in this case is shocking because of its emphasized gender markedness: "It was well for you that you were born a man. Freedom is of male gender" (notably, in the last sentence the method of denial of evident is used aimed to point to the possibility of living "on the other side of the law"), which is strengthened by the following video sequence: a long line of nearly undressed girls, probably participating in some competition (may be in a competition for men's attention?) is shown, then the guy enters into the room, who pays no attention to girls, but takes beer and drinks. Situation may be vice versa, where the intellectual or emotional dominance of females is outlined or males are shown as dependent and powerless (for instance, advertising of "Jacobs" coffee, "Coldrex" drug, etc.).

Sometimes, the gender markedness of advertising is caused by the type of the good itself, which is designed and suitable exclusively for women, or for men, or for their part, and sometimes it is caused by the specific advertising concept in case of advertising of common use goods (which is more frequently based on the opposition of lifestyles, aspirations, world perception of different gender groups). As far as the types of goods are concerned, studies of TV advertising performed by different scientists have shown that $39 \%$ of advertising products addressed to women are announcements, in which self-care goods are offered (cosmetics, perfumery products, drugs), while $61 \%$ of advertising products offer goods for house, children or man care [15, p. 69]. However, the majority of advertising products addressed to men offer goods, which are designed and suitable personally for men. One more external cause of the advertising products gender markedness may be the emphatic gender orientation of mass media (printed mass media, before everything else, rarer - TV channels, etc.), in which these advertising products are broadcasted.

Other cases of emphasizing the gender characteristics in advertising text are connected, before everything else, with the abundance of gender stereotypes, being some sort of social stereotypes, in the advertising area. Meanwhile, the analysis of the advertising market proves the universality of gender stereotypes for all principal types of advertising, including commercial, social and political advertising. In the two latter types, such stereotypes are of secondary significance (however, exceptions exist for such cases, as, for instance, social advertising directed against domestic violence in respect of women or some advertising blocks against AIDS propagation in the result of sex relations), while for commercial advertising these stereotypes form the core of the advertising concept.

The modes of generation and translation of male and female stereotype images, which are used in advertising and which may maximally correspond to specific features of collective expectations and perceptions of the society members in respect of gender relations, provide active correlation of the advertising area with the myth-making sphere. At the same time, cases of apparent destruction of stereotypes, sometimes forming the basis of the advertising concept, make it possible to create shocking, deviant advertising texts, which should bring to the desired result owing to originality, maximum distinction within advertising outflow, which is very important in the modern conditions of the oversaturation of the media scene with advertising information. In this connection, the investigators have noted that the creativity principle "...is based on the breach of dominant norms and traditions, archetypes and stereotypes" [16, p. 266]. According to A. Karmalova, great significance in the presentation of advertising stereotypes belongs to the humorous style, and "...since advertising does not avoid humor, different forms of 
gags, advertising text may become the scene for ironical presentation of "new myths" - hackneyed phrases and stereotypes of public consciousness" [17, pp. 86-87].

In our opinion, nowadays one can find close connection between gender and professional stereotypes existing in the advertising area. Profession is one of the demonstrative aspects characterizing the existence of gender stereotypes in advertising. Another aspects are connected with the roles, which persons of a certain gender play within the context of the advertising message, for instance, within advertising representations (the most distinctive - in TV spots), where the behavior of these persons is shown in everyday life, during rest, at work, in the shop, etc..

Considering this problem, E.Yu. Ilyinova has outlined the negative prevailing aspect of different stereotypes, correlating with "the socio-demographic characteristics of individuals, which are affected by public tempers, expectations and perceptions" [18, p. 32]. E.Yu. Ilyinova has noted: "At this point, we may satisfy ourselves of that predominantly negative role of stereotypes, which they play during generation and translation of socially limited perceptions. Here we mean gender ("women do not understand exact sciences"), social-role ("a woman cannot be the chief") and other stereotypes, which exist in society, become specific in particular sociocultural conditions, supported or ruptured by mass media" [18, p. 33].

Pursuant to investigations of Western psychologists [19], in TV advertising $70 \%$ of men are shown as experts in definite matters and $86 \%$ of women are shown as consumers of definite goods/services; the reasons for purchasing by men of the goods are social or career progress, while prevailing factors for the goods purchasing by women are connected with the emotional sphere and communications. In this regard, it is increasingly outlined that nowadays trends pertinent to the customary gender roles of males and females are subject to shift.

The analysis of the advertising area in former Soviet republics not only presents uncontestable facts supporting all suggested versions, but also demonstrates appearance of new stereotypes and gradual shift of emphasis.

Thus, following the opinion of Russian investigators [20], main versions of females' presentation in TV advertising are as follows: a woman as a householder (for instance, "Comet", "Gala", "Domestos", "Cif", "Fairy", "Broun", "Gallina Blanca", "Tefal", etc.); a woman as a sex object (for instance, "Ardo", "Chanel" and others), a woman as a synonym of beauty (for instance, "Lady Speed Stick", "Rexona", "Vichy", "Garnier", "Clearasil", "Chyornyi Zhemchug", etc.). It should be noted that nowadays women are increasingly presented as business women and in their professional capacities, which is caused by both real existing situation, as well as by entering of Western standards and traditions (for instance, "Dirol", "Persen", "LG", etc.).

It is indicative that the modern advertising area in former Soviet republics involves substantially different male stereotype images in TV advertising, namely: a man-hero (for instance, "Rexona for men" antiperspirant, "Teraflue" cough remedy, where infrequent in advertising, strictly male profession of sailor, shipmaster is shown, etc.); an active man (for instance, "Old Spice", "Lacoste", etc.); a married (family) male (for instance, "Libero", "MilkyWay" "Papa mozhet" and others); a man - supporter of the family (for instance, "Jacobs", etc.); a man at work (for instance, "LG" and others); an erotic man (for instance, "Head-and-Shoulders", "Sprite", "Gillette", "Axe", "Fa", etc.); a free man (for instance, "Samsung", etc.) [21].

Distinct textual corpus, which reproduces, translates or ruptures gender stereotypes, is represented by social advertising, which is initially designed with the aim to reflect difficult problems within the society and to offer methods of their solution, to introduce valuables and 
attitudes into the collective and individual consciousness. Meanwhile, it is common for social advertising to operate with generalized, "typical" for the society gender, age-related and professional images [22]. Thus, a variety of female persons may be found in the aforementioned advertising, designed to prevent AIDS propagation, in which young girls similar in appearance say "no" to sex without condoms, as well as in advertising with the slogan "You may be confident in your partner, but you can not be confident in his previous partners. Protect yourself from AIDS, use condom" and in others. In these examples, one can find at least two gender stereotypes, namely: problem of protection from AIDS must worry women, and the change of partners is incidental for males; both versions of behavior are presented as incontestable, the only possible and accepted by society.

In this context, the stereotype typology suggested by L. Guslyakova seems rather interesting; L. Guslyakova believes that stereotypes may be grouped based on subject rather than object of stereotypeness (representativeness). Respectively, two basically different stereotype groups are considered: those, which appear spontaneously, without any subject, and those, which are generated rationally, taking into account ideological, cultural and national factors [23, p. 64]. This concept may be directly used for advertising area, in which spontaneous, in many cases instinctively activated stereotypes (particularly, gender and professional ones) are used in parallel with consciously attracted, translated or transformed stereotypes, and in the latter case creative factors, based on use of definite stereotype, being in subordination of ad hoc pragmatic targets, may exert negative effect on public conscious and generate false value targets for the society members.

An important feature of TV advertising is its sexualization (by the way, in German the word "advertising" (die Werbung) verbally means "love desire"). Very often, goods are advertised on the TV screen using desirable sexual symbols or sexually tempting situations, and in $82 \%$ of such cases, the female body is used as the object of such advertisings. In videoclips, which are advertising construction materials, engine oils, computers, cars, furniture and other industrial products, the alluring beauty women dressed in bikini are used as a background. At the same time, naked male body is rarely used in such videoclips, which are advertising construction materials and cars [24].

One may find more than enough examples of advertising sexualization on the TV screen. Advertising of "Taller" beer (woman keeps bottles with beer in hands on naked breast), advertising of "Orbit" chewing gum (two teenagers gradually undress each other in a stair well) and others. In advertising video clips, we do not see the naked human body. Advertising decodes unconscious instincts and offers output of the released sexual energy via purchase. Such advertising accounts for selection of the manipulative tool, which exerts an effect on subconscious, on libido injection into conscious along with lowering of social restraints level.

Women are shown as the object of sexual interest in advertising of different goods. In such advertising, they are tempting, sexual, and perfect. Often in order to stress these features, ad makers undress women and take advantage of eroticism subject. Nowadays, the female body sells cosmetics, clothes, food, drinks, cars - all that you want. However, the male body is almost eliminated from sexual advertising area, while erotic male presentation in advertising has appeared only during the last decade. This is again caused by the stereotype, following which the female body is more attractive as compared to the male body [25].

Many investigations have been devoted to the study of male and female images, in which a lot of interesting facts have been found. For instance, in investigations of Russian scientists E.M. Zuykova and R.I. Yeruslanova it has been found that a woman in public consciousness is 
perceived as bearer of aesthetic function (pretty, diligent, attractive, feminine, charitable, humane, etc.), as compared with which such features as forgetfulness, expansivity, hysteric character, depressiveness, jealousy, talkativeness are not so important. At the same time, a man, despite of a number of values (mental agility, firmness, businesslike character, competence, centrality of purpose, etc.), is characterized in terms of aggression, barbarity, cruelty, egoism and aplomb [26, p. 24].

In general, it is believed that the male and female worlds are shown in the advertising area separately from each other and with emphasis on their interminable opposition, potential natural discrepancies, disparities of priorities, aspirations and preferences. Exactly in such context, the advertised goods look like more advantageous, as possessing with a "magic" capacity to eliminate these discrepancies and gender proneness to conflict.

\section{Analysis of gender stereotypes in magazine advertising}

With a view to investigate generation of gender images and stereotypes in modern advertising practice, we have realized a sampling analysis of print (magazine) advertising in female magazines published in different countries, in the Russian language, namely: international magazine "Cosmopolitan" [27], Russian magazine "Liza" [28], Ukrainian magazine "Natali" [29], as well as in international male magazine "XXL" [30].

1. Perfumery product "Baby Doll Yves Saint Laurent" [27, pp. 75-76]. In advertising, one can find 3 scent bottles and a dreamy young lady-model of nearly 25 years old. The sexualization level is medium (naked shoulders). The color emphasis is pink, which is congruent in this case. Since this lady-model, which became the spokesmodel of this brand, is rather young, the producers have determined the targeted audience of this product. That's why this picture is associated with mobility and youth, and the pink color of the bottle, lettering, the girl's blouse and roses on her cheeks are perfectly tied with these associations. The whole picture is completed. The painting of the text is rather low - only the name of the perfumery product, the manufacturer and the distributors' addresses. Advertising is rather effective. There are no doubts in the originality of the artist's intention and its implementation. Advertising is created in accordance with the preferences of the selected targeted audience, characterized by integral perception (good composition design, mobility is present), though the itemization level is excessive - three scent bottles are distributed almost at random; however, they attract a lot of attention. The symbol of a "young lady" is used as personification of innocence and chastity. Advertising is neutral from the gender point of view; however, gender markedness exists in name of the perfumery product "baby doll", though product is designed not for children, but for women.

2. Advertising of "Cif" detergent [28, p. 32]. Young lady-model (of not more than 30 years old) is a householder. The sexualization level is low, sexism is absent, the "woman-householder" stereotype is active. In order to strengthen the positive impression of the advertised product, the young lady presses it to her face. She declares full confidence to the quality of "Cif". Design implementation completely corresponds to the demands of targeted audience. Different gradations of grey color and pastel shades are used in advertising. The emphasis is on the brightyellow bottles with the advertised product. The slogan is written with dark letters on light background, which is corresponding to the effective design rules; however, the font is selected poorly.

3. "Safeguard" soap [29, p. 28]. Soap is advertised by the whole family: father, mother and son. Ad makers placed stake on the protective properties of this soap. Therefore, we feel implied 
sense in this advertising - the family needs protection at the microbacterial level, and the mother must exercise care for this, since just mother exercises care for fireside comfort and health of children. Thus, the targeted audience of this product is women, and advertising is designed for them. Every woman desires to have ideal family, where husband adores his wife, all is OK with them, and small and healthy children are added to this idyll. It turns out that when purchasing this soap, we are purchasing the dream about homely home and health. The originality of the artist's intention is not so high; however, the integrity level (family image) promotes presentation of unity of the idealized family and transfers positive emotions from family to the advertised product. Sexualization elements are absent in this picture.

Thus, it may be concluded that the form and content of the modern advertising in female magazines are quite qualitative and gender stereotypes are constantly used in it.

However, one of the most widespread stereotypes, which is translated in magazine advertising, is the image of a woman - guardian of the hearth, which characterizes a woman mainly in the private, family sphere.

In contrast, in the magazine advertising men are presented mainly as businesslike, formal or informal. Men more frequently are associated with success, initiative, and autonomy. In accordance with this approach, we will try to follow and analyze how men are presented, their place and role in society, field of interests, relations with women declared in advertisings published in male magazines.

\section{Analysis of the male representation}

Quad bikes advertising [30, pp. 90-91]. Purely male goods require strictly male advertising. Advertising is made in the action style, women and sexism are absent; however, advertising remained effective. The product is designed for male audience; therefore, this concept is reflected both in the artist's intention and in design originality, and is aimed to attract men's attention. Ad makers created an integral image of the advertised product, which coincided with the particular features of male perception. Therefore, the considered material is the example of qualitative male representation.

In general, if we compare male and female images, we will find apparent differences in their characters. The former are always connected with success, the leadership role and independence, while the latter are connected with inactivity and are focused on the satisfaction of male and female interests. In addition, women in advertising are often smiling and joyful, while men are serious. This is because stereotypic men earn money, while women spend them.

It should be noted that male magazines belong to the male world. On the one hand, these magazines allow women to know more about this part of mankind, and on the other hand, these magazines illustrate functioning and imposition by the society of stereotypes, both male and female ones, not only in terms just of the magazines, but also in the sense of advertising placed in the aforementioned magazines. For this reason, these magazines predominantly show male models and successful businessmen, politicians, artists and people of art, who keep a sharp lookout for their appearance, body, cloths, shoes, perfumery products. They even have fun just mannishly. Everything is focused on the forming of outer shell, that is to say, marketable appearance, which should be sold as profitable as possible - the more respectable a man looks, the more expensive perfume or tobacco he uses, the more possibilities he will have and the demand for him will grow. On the one hand, a positive character of such representation teaches a 
man to take care of his appearance and his education, focus on the career progress, however, on the other hand, it forms curious and sometimes false female notions about the standards of male beauty, male lifestyle, habits, etc. [31].

\section{Conclusion}

Thus, we have ascertained that modern advertising has a substantial effect on generation and fixation of gender stereotypes in public consciousness. Gender images and stereotypes, both those, which existed before, and those, which have appeared recently and which prevail in advertising texts and images, become permanent in consciousness of common people. However, gender stereotypes, in turn, largely determine the specific features of the modern advertising area. Applying gender psychology as a basis for market segmentation and an appeal to gender stereotypes are those principal factors, which may provide commercial and communicative effectiveness of advertising products, while gender-marked archetypical images and reasons, which emphasize the interminable opposition of the male and female, actively participate in generation of the modern advertising area.

The present-day mentality of Kazakhstan people retains a patriarchal character; therefore, despite social progress, a woman is still perceived based on stereotypic models, which have been generated and accepted during many centuries. Changing the gender stereotypes is a long and complex process. The patriarchal thinking paradigm reflects the world perception as some sort of architecture, containing polar elements along with those arranged in the form of a hierarchically structured model.

Further investigations in this field remain rather relevant keeping in mind the modern stage of advertising development, and their results may promote effective work of ad makers, who are moving in the direction from gender inequality towards egalitarian and well-balanced advertising.

\section{References}

Carter, C., \& Steiner, L. (2004). Critical Readings: Media and Gender. Maidenhead, UK: Open University Press, Milton Keynes.

Gauntlett, D. (2002). Media, Gender and Identity: An Introduction. London, UK: Routledge.

Eisend, M. (2010). A Meta-Analysis of Gender Roles in Advertising. Journal of the Academy of Marketing Science, 38, 418-440.

Bern, Sh. (2007). Gendernaya psikhologiya [Gender Psychology]. Saint Petersburg: Praim-Evroznak.

Deaux, K., \& Lewis, L.L. (1984). Structure of Gender Stereotypes: Interrelationships among Components and Gender Label. Journal of Personality and Social Psychology, 46, 991-1004.

Popa, D., \& Gavriliu, D. (2015). Gender Representations and Digital Media. Procedia - Social and Behavioral Sciences, 180, 1199-1206.

Petrov, M.S. (2010). Gendernye obrazy i stereotipy sovremennoi rossiiskoi reklam [Gender Images and Stereotypes in Modern Russian Advertising]. Izvestiya Rossiiskogo gosudarstvennogo pedagogicheskogo universiteta im. A.I. Gertzena, 124, 38-49. 
Groshev, I.V. (1998). Polorolevye stereotipy v reklame [Gender Role Stereotypes in Advertising]. Psikhologicheskii zhurnal, 19(3), 119-133.

Groshev, I.V. (200o). Gendernye obrazy reklamy [Advertising Gender Images]. Voprosy psikhologii, 6, 38-49.

Tomskaya, M.V. (2001). Gendernyi aspekt sotsialnogo reklamnogo diskursa [Gender Aspect of Social Advertising Discourse]. In Gender: yazyk, kultura, kommunikatsiya: Doklady Pervoi Mezhdunarodnoi konferentsii [Gender, Language, Culture, Communication: Proceedings of the First International Conference] (pp. 328-333). Moscow.

Tomskaya, M.V. (1999). Gendernaya kharakteristika sotsialnoi reklamy (verbalnye i neverbalnye komponenty) [Gender Characteristics of Social Advertising (Verbal and Non-verbal Components)]. In Gender: yazyk, kultura, kommunikatsiya: Doklady Pervoi Mezhdunarodnoi konferentsii [Gender, Language, Culture, Communication: Proceedings of the First International Conference] (pp. 294-299). Moscow.

Cortese, A.J. (1999). Provocateur, Images of Women and Minorities in Advertising. New York, NY: Rowman and Littlefield Publishers.

Zotos, Y.C., \& Tsichla, E. (2014). Female Stereotypes in Print Advertising: A Retrospective Analysis. Procedia - Social and Behavioral Sciences, 148, 446-454.

Klassen, M.L., Jasper, C.R., \& Schwartz, A.M. (1993). Men and Women: Images of Their Relationships in Magazine Advertisements. Journal of Advertising Research, 33, 30-39.

Voronina, O.A. (1998). Gendernaya ekspertiza zakonodatelstva Rossiiskoi Federatsii o sredstvakh massovoi informatsii [Gender Expertise of Legislation of the Russian Federation on Mass Media]. Moscow: MCGI. (p. 152).

Wells, W., Bernet, J., \& Moriarti, S. (2008). Reklama: printsipy i praktika [Advertising: Principles and Practice]. Saint Petersburg: Piter. (p. 736).

Karmalova, E.Yu. (2008). Mifopoeticheskii analiz reklamnogo diskursa [Myth-Poetic Analysis of Advertising Discourse]. Vestnik Moskovskogo universiteta. Seriya 10: Zhurnalistika, 3, 85-95.

Ilyinova, E.Yu. (2010). Reklamnyi diskurs: tsennosti, obrazy, assotsiatsii [Advertising Discourse: Values, Images, Associations]. In T.N. Kolokoltseva (Ed.), Reklamnyi diskurs i reklamnyi tekst: Kol. monografiya [Advertising Discourse and Advertising Text: Collective Monography] (pp. 30-45). Volgograd: Publ. House VGPU Peremena.

Odekerken-Schröder, G., De Wulf, K., \& Hofstee, N. (2002). Is Gender Stereotyping in Advertising More Prevalent in Masculine Countries? A Cross-National Analysis. International Marketing Review, 19, 408419 .

Spasov, V.D. (2016). Ispolzovanie gendernykh stereotipov v sovremennykh reklamnykh tekhnologiyakh [Usage of Gender Stereotypes in Modern Advertising Technologies]. PR i reklama $v$ izmenyayushchemsya mire: regionalnyi aspekt, 14, 24-32.

Belinskaya, D.V. (2010). Vizualnaya reprezentatsiya muzhskikh i zhenskikh obrazov [Visual Representation of Male and Female Images]. Aktualnye innovatsionnye issledovaniya: nauka i praktika, 4, 13-19.

Robertson, K., \& Davidson, J. (2013). Gender-Role Stereotypes in Integrated Social Marketing Communication: Influence on Attitudes towards the Ad. Australasian Marketing Journal, 21(3),168-175.

Guslyakova, L. (1990). Chto takoe stereotip i nado li s nim borotsya? [What is Stereotype and Should We Fight With It?]. In T. Shmeleva (Ed.), Pokushenie na nezyblemoe ili...?: Stereotipy sotsialnopoliticheskogo soznaniya i perestroika [Attempt for Foundation or...? Stereotypes of Social-Political Conscious and Perestroyka] (pp. 135-149). Barnaul.

Gilly, M.C. (1988). Sex Roles in Advertising: A comparison of television advertisements in Australia, Mexico and the United States. Journal of Marketing, 52, 75-85. 
128 | Modern Advertising Practice: Gender Images and Stereotypes Generation

Napoli, J., Murgolo-Poore, M., \& Boudville, I. (2003). Female Gender Images in Adolescent Magazine Advertising. Australasian Marketing Journal, 11(1), 60-69.

Zuykova, E.M., \& Eruslanova, R.I. (2007). Feminologiya i gendernaya politika [Feminology and Gender Policy]. Moscow: Dashkov \& Co.

Cosmopolitan, 4. (2017).

Liza, 1. (2017).

Natali, 9. (2016).

XXL, 8. (2016).

Ermakovich, S.P. (2013). Metadiskurs "muzhskoi" reklamy [Metadiscourse of "Male" Advertising]. In Kommunikatsiya $v$ sovremennom polikulturnom mire: etnopsikholingvisticheskii analiz [Communication in the Modern Polycultural World: Ethnopsycholinguistic Analysis] (pp. 236-248). Moscow. 